\title{
Analysis of Influencing Factors of China's Agricultural Products Exports to SCO Based on CMS Model
}

\author{
Huiqing Sun ${ }^{1, \mathrm{a}}$,Qingrou Zhong ${ }^{* 2, \mathrm{~b}}$,Ling Yang ${ }^{* 3, \mathrm{c}}$ \\ ${ }^{1}$ School Economics \&Trade Xinhua College of Sun Yat-sen University, Guangzhou, China \\ ${ }^{2}$ School Economics \&Management Harbin University of Science and Technology, Harbin, China \\ ${ }^{3}$ School Economics \& Trade Xinhua College of Sun Yat-sen University, Guangzhou, China
}

\begin{abstract}
This article applies CMS model and selects the data about exports of agricultural products to all the other members of Shanghai Cooperation Organization (SCO) except for China from 1998 to 2018 to decompose the influencing factors of exports of agricultural products from China to all the other members of SCO. The results show that the competitiveness effects plays an important role in promoting the growth of exports while structural change effects is the inhibition effect.
\end{abstract}

\section{Research background}

Currently, the prospect of global trade in 2021 is predicted to possibility present the L-shape recovery. Due to the effect of trade environment, policy and epidemic situation, global trade will be severely affected. In 2017, the numbers of the members of SCO firstly increase to 8, which significantly promote the agricultural products' trade among members. Therefore, it is of great significance to discuss the influencing factors of China's agricultural products exports to all the other members of SCO.

The current research about the trade of agricultural products from China to the members of SCO focus on two aspects: one is the research of trade between China and each member of SCO (Lin Tao \& Huang Yinduan[1]; Gong Xinshu, Zhang Xiaoqian \& Zhang Ruihua [2]; Hu Ying[3]; Fang Yuan et al. [4]; Beisheev Ulan[5]; Zhang Yuhua et al.[6]; Hu Guoliang,Luo Qiuyi \& Wang Yanbing[7] etc); the second is the research about agricultural products' trade among all the other members of SCO except for China( Zhang Mingyu[8]; Zheng Guofu[9]; Zhang Xiaoqian \& Gong Xinshu[10]; Xia Yong, Zhang Qinhong \& Cao Shoufeng[11].

In Summery, there are less research about the influencing factors of agricultural products' exports increase from China to all the other members of SCO. Therefore, this article construct the CMS model and focus on all the other members of SCO as a whole to analyze the influencing factors from China to all the other members of SCO.

\section{The status of China agricultural products' export to other members of SCO}

\subsection{The scale of agricultural products' export has been expanding from China to SCO}

In 2018, the total value of China's exports of agricultural products to all the other members of SCO reached 3.686 billion dollars which is $60.68 \%$ higher than that in 2016 , 12.26 times higher than that in 2001, and 8.7 times higher than that in 1998 respectively. Meanwhile, the total value constantly expand. In the same year, the total value of agricultural products' export from China to the other 5 members of original countries increased by 0.217 billion dollars (9.46\%) compared with 2016. Between 2001 and 2008 , the annual growth rate of total value for agricultural products' export from China to all the other members reached $61 \%$. However, it began to decrease in 2009 and did not increase significantly until 2017 when SCO expanded and the total volume of trade increase rapidly, as shown in Table1.

Table1. The total value of agricultural products' export From China to SCO

\begin{tabular}{|c|c|c|c|c|c|c|c|c|c|c|c|}
\hline Year & $\mathbf{1 9 9 8}$ & $\mathbf{1 9 9 9}$ & $\mathbf{2 0 0 0}$ & $\mathbf{2 0 0 1}$ & $\mathbf{2 0 0 2}$ & $\mathbf{2 0 0 3}$ & $\mathbf{2 0 0 4}$ & $\mathbf{2 0 0 5}$ & $\mathbf{2 0 0 6}$ & $\mathbf{2 0 0 7}$ & $\mathbf{2 0 0 8}$ \\
\hline Total value & 3.8 & 2.14 & 2.06 & 2.78 & 4.89 & 6.28 & 6.38 & 7.98 & 9.87 & 13.93 & 16.27 \\
\hline Year & $\mathbf{2 0 0 9}$ & $\mathbf{2 0 1 0}$ & $\mathbf{2 0 1 1}$ & $\mathbf{2 0 1 2}$ & $\mathbf{2 0 1 3}$ & $\mathbf{2 0 1 4}$ & $\mathbf{2 0 1 5}$ & $\mathbf{2 0 1 6}$ & $\mathbf{2 0 1 7}$ & $\mathbf{2 0 1 8}$ & \\
\hline Total value & 13.96 & 18.12 & 23.25 & 23.44 & 25.11 & 27.76 & 22.43 & 22.94 & 37.24 & 36.86 & \\
\hline
\end{tabular}




\subsection{The agricultural products' exporting countries unevenly distributed}

The exports of agricultural products from China to each member of SCO are different, as shown in Figure I. The exports from China to Russia rank the first place compared to other countries for a long time. It accounted for over $80 \%$ of total exports from China to all the other members of SCO between 1998 and 2016, and decreased to over 50\% when SCO expanded in 2017, but absolute amount still increase.

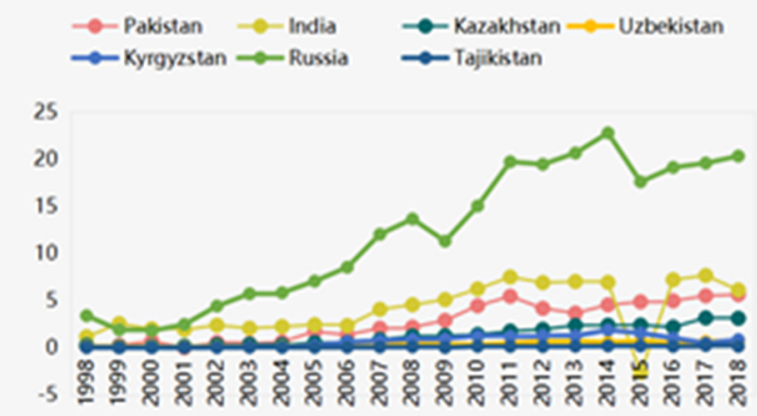

Figure I. The value of agricultural products' export to each member of SCO

\subsection{The structure of agricultural products' exports is centralized}

As shown in Table 2, the structure of agricultural products mainly focus on Category 0 which accounts for over $75 \%$ in each year and the highest proposition can reach $94.11 \%$. The exports of Category 1 and 2 is stable and the exports of Category 4 increased. But even Pakistan and India participate in the organization, the exports value of Category 2 and 4 cannot reach 100 million dollars. Therefore, the structure of agricultural products' exports is centralized.

Table2. The proportion of different categories of agricultural products exported by China to SCO members

\begin{tabular}{ccccc}
\hline Year & $\begin{array}{c}\text { Category } 0 \\
(\%)\end{array}$ & $\begin{array}{c}\text { Category } 1 \\
(\%)\end{array}$ & $\begin{array}{c}\text { Category } 2 \\
(\%)\end{array}$ & $\begin{array}{c}\text { Category } 4 \\
(\%)\end{array}$ \\
\hline 1998 & 88.42 & 6.58 & 4.74 & 0.26 \\
\hline 1999 & 77.10 & 9.35 & 13.55 & 0.00 \\
\hline 2000 & 77.67 & 11.17 & 11.17 & 0.00 \\
\hline 2001 & 79.14 & 8.27 & 12.59 & 0.00 \\
\hline 2002 & 86.89 & 4.92 & 7.99 & 0.20 \\
\hline 2003 & 86.31 & 3.34 & 10.19 & 0.16 \\
\hline 2004 & 87.62 & 2.35 & 9.56 & 0.47 \\
\hline 2005 & 89.60 & 1.50 & 8.65 & 0.25 \\
\hline 2006 & 93.21 & 1.32 & 5.37 & 0.10 \\
\hline 2007 & 93.11 & 1.08 & 5.67 & 0.14 \\
\hline 2008 & 91.83 & 1.11 & 6.76 & 0.31 \\
\hline 2009 & 94.13 & 1.29 & 4.30 & 0.29 \\
\hline 2010 & 92.44 & 1.21 & 6.13 & 0.22 \\
\hline 2011 & 90.03 & 1.33 & 8.30 & 0.34 \\
\hline
\end{tabular}

\begin{tabular}{lllll}
\hline 2012 & 91.34 & 1.19 & 7.12 & 0.34 \\
\hline 2013 & 93.07 & 1.04 & 5.66 & 0.24 \\
\hline 2014 & 93.01 & 0.68 & 6.05 & 0.25 \\
\hline 2015 & 93.49 & 0.58 & 5.71 & 0.22 \\
\hline 2016 & 93.33 & 0.92 & 5.54 & 0.22 \\
\hline 2017 & 76.97 & 0.81 & 21.80 & 0.43 \\
\hline 2018 & 75.41 & 1.11 & 22.42 & 1.06 \\
\hline
\end{tabular}

\section{Empirical analysis of influencing factors of agricultural products' exports from China to all the other members of SCO}

\subsection{Data selection}

This article selected the following 4 categories as research object according to SITC Rev.3: Category 0, Category 1, Category 2 (except for chapters 27 and 28), Category 4. This article selected the data from 1998 to 2018 to construct a CMS model and take all the other members of SCO as a whole. The data between 1998 and 2016 is the trade between China and the original 5 members of SCO but the data after 2017 is the trade between China and 7 members.

\subsection{Model Construction}

This article draws on the single mareket CMS model constructed by $\mathrm{Lu}$ Yanpin \& Xiao Haifeng[12] and decomposes the CMS model into two levels, with the following model:

The first level of decomposition:

$$
\Delta \mathrm{q}=\sum_{i} S_{i}^{0} \Delta Q i+\sum_{i} Q_{\mathrm{i}}^{0} \Delta S_{i}+\sum_{i} \Delta S_{i} \Delta Q_{\mathrm{i}}
$$

The second level of decomposition:

$$
\begin{aligned}
& \Delta \mathrm{q}=S^{0} \Delta Q+\left(\sum_{i} S_{i}^{0} \Delta Q i-S^{0} \Delta Q\right)+\Delta S Q^{0}+\left(\sum_{i} Q_{\mathrm{i}}^{0} \Delta S_{i}-\Delta S Q^{0}\right) \\
& +\left(\frac{Q^{1}}{Q^{0}}-1\right) \sum_{i} \Delta S_{\mathrm{i}} Q_{i}^{0}+\left[\sum_{i} \Delta S_{i} \Delta Q_{\mathrm{i}}-\left(\frac{Q^{1}}{Q^{0}}-1\right) \sum_{\mathrm{i}} \Delta S_{i} \Delta Q_{\mathrm{i}}^{0}\right]
\end{aligned}
$$

Among them, $\Delta q$ represents the changes of agricultural products' exports from China to all the other members of SCO. $\sum_{i} S_{i}^{0} \Delta Q i$ represents the structural change effect which can be decomposed into world growth effect $\left(S^{0} \Delta Q\right)$ and commodity effect ( $\left.\sum S_{i}^{0} \Delta Q i-S^{0} \Delta Q \quad\right) . \quad \sum Q_{i}^{0} \Delta S_{i}$ presents the competitiveness effects which can be decomposed into comprehensive competitiveness effects $\left(\Delta S Q^{0}\right)$ and commodity competitiveness effects $\left(\sum_{i} Q_{i}^{0} \Delta S_{i}-\Delta S Q^{0}\right)$; $\sum \Delta S_{i} \Delta Q_{\mathrm{i}}$ presents the interaction effect which can be decomposed into Pure second-order effect $\left.\left({ }_{(} \frac{Q^{1}}{Q^{0}}-1\right) \sum_{i} \Delta S_{i} Q_{i}^{0} \quad\right)$ and dynamic second-order effect 


$$
\left(\sum_{i} \Delta S_{i} \Delta Q_{\mathrm{i}}-\left(\frac{Q^{1}}{Q^{0}}-1\right) \sum_{\mathrm{i}} \Delta S_{i} \Delta Q_{\mathrm{i}}^{0}\right)
$$

\subsection{Empirical Analysis}

\subsubsection{Phase division}

As shown in Table 3, the fluctuation index for the period from 1998 to 2000 was negative and the exports of agricultural products from China to all the other members of SCO decreased slowly. The average absolute value of fluctuation index between 2009 and 2014 is only 0.151 and the fluctuations are relatively flat. Combining the fluctuation and considering on the the effect of important events on the trade, the periods between 1998 and 2018 can be divided into 5 stages: 1998-2000, 2001-2008, 2009-2014, 2015-2016, 2017-2018.

Table3. fluctuation Index of Exports of Agricultural Products to menbers of SCO from 1998 to 2018

\begin{tabular}{cccccccc}
\hline Year & 1999 & 2000 & 2001 & 2002 & 2003 & 2004 & 2005 \\
Fluctuation Index & -0.437 & -0.037 & 0.350 & 0.759 & 0.284 & 0.016 & 0.251 \\
\hline Year & 2006 & 2007 & 2008 & 2009 & 2010 & 2011 & 2012 \\
Fluctuation Index & 0.237 & 0.411 & 0.168 & -0.142 & 0.298 & 0.283 & 0.008 \\
\hline Year & 2013 & 2014 & 2015 & 2016 & 2017 & 2018 & \\
Fluctuation Index & 0.071 & 0.106 & -0.192 & 0.023 & 0.623 & -0.010 & \\
\hline
\end{tabular}

\subsubsection{Results analysis}

(a) Competitiveness effects is an important factor in promoting the agricultural products' exports from China to all the other members of SCO.

The competitiveness effects reflects the impact of the increased of China agricultural products' competitiveness on the agricultural products' exports from China to all the other members of SCO. In the first stage, the competitiveness effect is negative, which inhibits the agricultural products' exports from China to all the other members of SCO. However, in the succeeding stages, the competitiveness effect began to promote the agricultural products' exports from China to all the other members of $\mathrm{SCO}$ and the effect continued to strengthen. As shown in the Table 4, from 2001 to 2008 , the competitiveness effect led to the increase of agricultural products' exports by 134.86 million dollars and the contribution rate was only 10\%. As shown in the Table 5, from 2015 to 2016, the contribution rate increased to $346.14 \%$ while it reached $659.89 \%$ between 2017 and 2018, in general, China's competitiveness in the market of SCO for agricultural products has been increasing. Comprehensive competitiveness effect plays a major role in the competitiveness effect and the effect direction is consistent with the competitiveness effect, but commodity competitiveness effect is weaker than the comprehensive competitiveness effect. Commodity competitiveness effect changed from negative to positive during the period from 2015 to 2016 and reached $93.8 \%$, then increased to 143.94\% between 2017 and 2018. The commodity competitiveness effect constantly increased, which indicates the exports of specific agricultural products from China to SCO increase and improve the exports.

(b) The inhibition of structural effect is obvious

From 1998 to 2000, the structural effect inhibited the growth of exports from China to all the other members of SCO, but the world growth effect in this period was negative and the commodity effect was positive, which indicates that the export structure of China's agricultural products match with the market demand of SCO to some extent. The structural change effect was $59.28 \%$ from 2001 to 2008, and $48.94 \%$ from 2009 to 2014, which indicates the expansion of import demands of SCO members and match of China agricultural products structure with imports demands of SCO members during these two periods improved Chinese exports. The main factor is that the import demand of agricultural products for SCO members expanded, which can embodied in the contribution rate of world growth effect in these two periods of $58.69 \%$ and $47.43 \%$, respectively. However, in the other two periods, the structural effect were all negative and the value increased. The global economic downturn in 2015 reduced the import demand of SCO members for agricultural products, caused agricultural products' export from China to all the other members of SCO decreased by 115.54 million dollars. Both the world growth effect and commodity effect were all negative.

(c) Interaction effect raises first then falls, the influence of pure second-order effect and dynamic second-order effect alternately transforms

Interaction effect was positive between 1998 and 2014 and promotes the exports from China to SCO members. However, it turned to negative between 2015 and 2018. Due to dual tailwinds of China's accession and foundation of $\mathrm{SCO}$, and the high speed of global economic increase, the acceleration of interaction effect between 2001 and 2008 was obvious, with the contribution rate being $30.73 \%$ which was over than the competitiveness effect in the same period and led to the exports increase by 414.59 million dollars. Among them, pure second-order effect opposed a bigger role in promoting in the first three period, but after the two periods, pure second-order effect and dynamic second-order effect turned to negative, even the dynamic second-order effect was over than pure secondorder effect from 2017 to 2018, which presents dynamic second-order effect played a bigger role in inhibiting and this shows the interaction between the competitiveness of China's agricultural products and the relative export structure plays a higher inhibition role in export increase from China to all the other members of SCO .

Table4. The results of China's EXport of CMS to SCO from 1998 to 2014

\begin{tabular}{|c|c|c|c|c|}
\hline \multirow{3}{*}{$\begin{array}{l}\text { Influencing } \\
\text { factors }\end{array}$} & \multicolumn{4}{|c|}{ Unit: million dollars } \\
\hline & $1998-2000$ & 2001-2008 & 2009 & -2014 \\
\hline & Exports $\begin{array}{l}\text { Contribu } \\
\text { tion rate }\end{array}$ & Exports $\begin{array}{l}\text { Contribu } \\
\text { tion rate }\end{array}$ & Exports & $\begin{array}{l}\text { Contribu } \\
\text { tion rate }\end{array}$ \\
\hline $\begin{array}{l}\text { changes in } \\
\text { export value }\end{array}$ & $-174.77-100 \%$ & 1349.31 & 1345.20 & $100 \%$ \\
\hline $\begin{array}{c}\text { structural } \\
\text { change effect }\end{array}$ & $-114.16-65.32 \%$ & $59.28 \%$ & 658.30 & $48.94 \%$ \\
\hline
\end{tabular}




\begin{tabular}{ccccccc}
\hline $\begin{array}{c}\text { world growth } \\
\text { effect }\end{array}$ & -116.72 & $-66.79 \%$ & 791.91 & $58.69 \%$ & 638.08 & $47.43 \%$ \\
\hline $\begin{array}{c}\text { commodity } \\
\text { effect }\end{array}$ & 2.56 & $1.47 \%$ & 7.95 & $0.59 \%$ & 20.22 & $1.50 \%$ \\
\hline $\begin{array}{c}\text { competitivenes } \\
\text { s effects }\end{array}$ & -84.96 & $-48.62 \%$ & 134.86 & $10.00 \%$ & 474.78 & $35.29 \%$ \\
\hline $\begin{array}{c}\text { comprehensive } \\
\text { competitivenes }\end{array}$ & -83.83 & $-47.96 \%$ & 144.89 & $10.74 \%$ & 489.05 & $36.36 \%$ \\
\hline $\begin{array}{c}\text { commodity } \\
\text { competitivenes }\end{array}$ & -1.14 & $-0.65 \%$ & -10.02 & $-0.74 \%$ & -14.27 & $-1.06 \%$ \\
\hline $\begin{array}{c}\text { interaction } \\
\text { effect }\end{array}$ & 24.36 & $13.94 \%$ & 414.59 & $30.73 \%$ & 212.12 & $15.77 \%$ \\
\hline $\begin{array}{c}\text { pure second- } \\
\text { order effect }\end{array}$ & 26.05 & $14.91 \%$ & 383.98 & $28.46 \%$ & 211.71 & $15.74 \%$ \\
\hline $\begin{array}{c}\text { dynamic } \\
\text { second-order }\end{array}$ & -1.69 & $-0.97 \%$ & 30.61 & $2.27 \%$ & 0.41 & $0.03 \%$ \\
\hline
\end{tabular}

Table5. The results of China's EXport of CMS to SCO from 2015 to 2018

\begin{tabular}{ccccc}
\hline \multirow{2}{*}{$\begin{array}{c}\text { Influencing } \\
\text { factors }\end{array}$} & \multicolumn{2}{c}{$2015-2016$} & \multicolumn{2}{c}{$2017-2018$} \\
\cline { 2 - 5 } & Exports & $\begin{array}{c}\text { Contribution } \\
\text { rate }\end{array}$ & Exports & $\begin{array}{c}\text { Contribution } \\
\text { rate }\end{array}$ \\
\hline $\begin{array}{c}\text { changes in export } \\
\text { value }\end{array}$ & 51.55 & $100 \%$ & -38.15 & $-100 \%$ \\
\hline $\begin{array}{c}\text { structural change } \\
\text { effect }\end{array}$ & -115.54 & $-224.14 \%$ & -250.64 & $-656.99 \%$ \\
\hline $\begin{array}{c}\text { world growth } \\
\text { effect }\end{array}$ & -74.22 & $-143.99 \%$ & -223.19 & $-585.02 \%$ \\
\hline $\begin{array}{c}\text { commodity effect } \\
\begin{array}{c}\text { competitiveness } \\
\text { effects }\end{array}\end{array}$ & -41.32 & $-80.15 \%$ & -27.46 & $-71.97 \%$ \\
\hline $\begin{array}{c}\text { comprehensive } \\
\text { competitiveness }\end{array}$ & 130.08 & $252.34 \%$ & 196.83 & $515.95 \%$ \\
\hline $\begin{array}{c}\text { commodity } \\
\text { competitiveness }\end{array}$ & 48.36 & $93.80 \%$ & 54.91 & $143.94 \%$ \\
\hline \begin{tabular}{c} 
interaction effect \\
\hline pure second-order \\
effect
\end{tabular} & -11.34 & $-22.00 \%$ & -39.26 & $-102.90 \%$ \\
\hline $\begin{array}{c}\text { dynamic second- } \\
\text { order effect }\end{array}$ & -5.44 & $-10.55 \%$ & -24.17 & $-63.35 \%$ \\
\hline
\end{tabular}

\section{Conclusions and Recommendations}

This article analyzes the exports increase from China to SCO members. The results show that competitiveness effect is the main influencing factor of the increase of agricultural products' export and the structural effect plays an main inhibition effect.

In order to further facilitate agricultural products' export increase from China to SCO members, several measures can be taken:

- Continue to improve application of cross-border e-commerce on the export market of agricultural products from SCO members. In 2004, SCO found $\mathrm{Ad} \mathrm{Hoc}$ working group and it passed a document named Ideas of the SCO Member States on cooperation in the field of digitalization and information and communication technologies, meanwhile, the members of $\mathrm{SCO}$ pushed forward the development of cross-border e-commerce but there is a large developmental difference of cross-border e-commerce among SCO members ${ }^{1}$. Russia and Kazakhstans have signed memoranda of cooperating in the field of cross-border e-commerce and establishing bilateral cooperation mechanism of cross-border e-commerce ${ }^{2}$. They explored a new channel, new model and new point of developing agricultural products with the help of "Silk Road Electricity".

- After 2015, the structural effect played the inhibition role on the export increase. Therefore, China should improved the structure of export product to enhance the fitness with the import scale and structure of SCO members.

- Competitiveness of agricultural products should be improved, especially for Category 2. The detailed measures include strengthening the monitor of quality safety, especially for health sanitation safety in some steps such as the storage, transportation and sale etc which should be higher required.

* Corresponding author. The research of this paper was funded by the construction project of "Public Management", a key discipline with characteristics in Guangdong Province in 2016."Internet + Hybrid Teaching Mode Reform Project "Intermediate Microeconomics" (Project No. 2018HHJG011); "Internet Finance" course general education Research (Project Number 2019J014)

\section{Reference}

1. T. Lin and Y. D. Huang, "Analysis Of Trade Relations Between China And India In Agricultural Products Under The Background Of One Belt And One Road," Asia-pacific Economic Review, vol. 3, pp. 4552+149-150, 2020.

2. X. S. Gong, X. Q. Zhang and R. H. Zhang, "Research On The Fluctuation Factors Of China's Agricultural Exports To Kazakhstan Based On CMS Model," Guangdong Agricultural Sciences, vol. 41, pp. 201206, 2014.

3. Y. Hu, "China's Agricultural Export Growth to Kyrgyzstan -- An Analysis Based on CMS Model," Foreign Trade, vol. 8, pp. 11-13, 2012.

4. Y. Fang, "Analysis Of Factors Influencing IntraIndustry Trade Of Agricultural Products Between China and Kyrgyzstan," World Agriculture, vol. 5, pp. 50-53, 2012.

5. U. BEISHEEV, "Analysis On The Competitiveness of China's Agricultural Exports To Kyrgyzstan," Lanzhou University of Technology, Lanzhou, 2019.

6. Y. H. Zhang, X. Xiang et al, "Current Situation And Prospect of Agricultural Cooperation Between China and Tajikistan," World Agriculture, vol. 6, pp. 111113+164, 2013.

7. G. L. Hu, Q. Y. Luo, and Y. B. Wang, "Analysis on The Competitiveness and Complementarity of Chinese and Russian Agricultural Products Trade," Marketing Research, vol. 5, pp. 24-28, 2020.

\footnotetext{
1 http://www.sco-ec.gov.cn/article/cooperationsurvey/ trademeeting/201912/415406.html
}

2 https://www.yidaiyilu.gov.cn/ 
8. M. Y. Zhang, Q. Y. Luo, and Y. B. Wang, "Analysis of Trade Potential and Trade Efficiency Among SCO Member States," Tianjin Polytechnic University, Tianjin, 2017.

9. G. F. Zheng, "Agricultural Trade Cooperation Between China and Members of The Shanghai Cooperation Organisation: Spatio-Temporal Characteristics of Competition And Cooperation And Prospects," Regional and Global Development, vol. 5, pp.116-132+159, 2019.

10. Q. X. Zhang, and X. S. Gong, "Study on the Impact of SCO Trade Facilitation On China's Agricultural Exports -- Empirical Analysis Based on Panel Data," International Economics and Trade Research, vol. 1, pp. 28-38, 2015.

11. Y. Xia, Q. H. Zhang, S. F. Cao, "Research on the Growth Trend of China's Agricultural Exports to The SCO Countries," Statistics and Decision, vol. 20, pp. 79-82, 2013.

12. Y. P. Lu. and X. F. Xiao, "Analysis of Influencing Factors of Trade Pattern Fluctuation of Cashmere And Its Products In China -- Empirical Study Based on CMS Model," Agricultural Economics and Management, vol. 4, pp. 53-61, 2019. 